\title{
Enantioselective Dearomatization of Indoles
}

\section{Key words}

allenamides

dearomatization

quaternary carbon

centers<smiles>[R]c1[nH]c2ccc([Tl])cc2c1[R]</smiles><smiles>[CH2+]</smiles>

$\mathrm{R}^{1}=\mathrm{Alk}, \mathrm{Bn}$

$\mathrm{R}^{2}=$ Alk

$\mathrm{R}^{3}=\mathrm{H}, \mathrm{Hal}$, OAlk, Alk

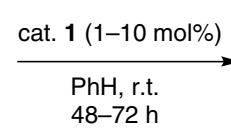

$R^{4}=T s, B s$ $48-72 \mathrm{~h}$

Selected examples of dearomatization-hydrogen transfer cascade:<smiles>CC1Nc2ccccc2[C@]1(C)/C=C/[NH3+]</smiles>

$51 \%$ yield

er trans $=99: 1$

$\mathrm{er}_{\text {cis }}=91: 9$

$\mathrm{dr}=19: 1$

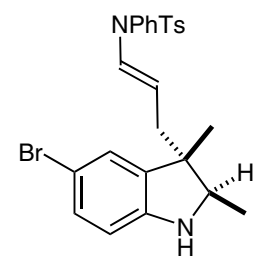

$60 \%$ yield

$\mathrm{er}_{\text {trans }}=97.5: 2.5$

$\mathrm{er}_{\text {cis }}=91: 9$

$\mathrm{dr}=10: 1$

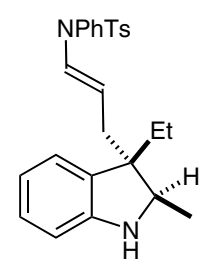

$49 \%$ yield

$\mathrm{er}_{\text {trans }}=99.5: 0.5$

$\mathrm{er}_{\text {cis }}=66.5: 33.5$

$\mathrm{dr}=15: 1$

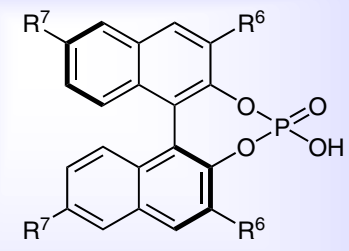

$\mathrm{R}^{6}=2,4,6-\mathrm{Cy}_{3} \mathrm{C}_{6} \mathrm{H}_{2} \quad(R)$-cat. 1 $\mathrm{R}^{7}=\mathrm{H}, \mathrm{C}_{8} \mathrm{H}_{17}$

\section{Selected examples:}

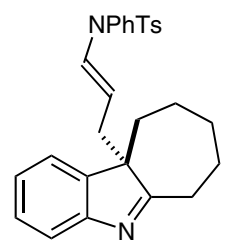

$51 \%$ yield er $=95.5: 4.5$<smiles>CC1=Nc2ccccc2C1(C/C=C/NS(=O)(=O)c1ccccc1)c1ccccc1</smiles>

$87 \%$ yield er $=97: 4$

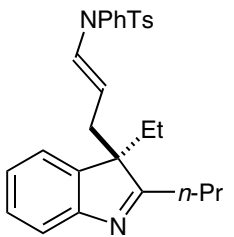

$69 \%$ yield er $=93.5: 6.5$ using (S)-cat. 1

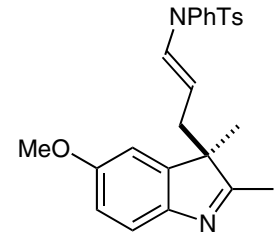

$60 \%$ yield er $=96: 4$ using (S)-cat. 1

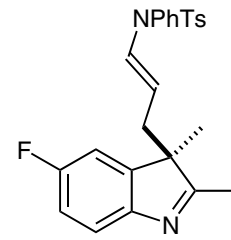

$64 \%$ yield er $=95.5: 4.5$ using $(S)$-cat. 1
Significance: Bandini and co-workers report an enantioselective dearomatization of indoles. Using 1 to 10 mol\% of chiral phosphoric acid catalyst $\mathbf{1}$, the desired 3,3-disubstituted indolenines are obtained in moderate to high yields and good to excellent enantioselectivities.
Comment: The authors developed an enantioselective electrophilic activation of allenamides, generating enantioenriched dearomatized 3,3-disubstituted indolenines as products. Additionally, a dearomatization-hydrogen transfer cascade was conducted. Performing the reaction in the presence of molecular sieves and Hantzsch ester, the corresponding indolines are obtained in good yields and with high diastereo- and enantioselectivities.

SYNFACTS Contributors: Benjamin List, Lisa Kötzner

Dol: 10.1055/s-0034-1379623; Reg-No.: B12614SF 